foreign policy in support of shared European interests and values. Main programmes: Russia and wider Europe; China; democracy, human rights and the rule of law.

Address: 35 Old Queen St., London SW1H 9JA, UK.

Website: http://www.ecfr.eu

President: Asger Aamund.

\section{European Policy Centre}

Independent, non-profit think tank committed to making European integration work. Aims to promote a balanced dialogue between the different constituencies of its membership, spanning all aspects of economic and social life. Programmes: EU integration and citizenship; Europe's political economy; Europe in the world.

Address: Résidence Palace, 155 rue de la Loi, B-1040 Brussels, Belgium.

Website: http://www.epc.eu

Chairman: Peter Sutherland.

\section{European Union Institute for Security Studies}

Founded 2001. Autonomous EU agency operating under the Common Foreign and Security Policy (CFSP). Aims to find a common security culture for the EU, develop and project the CFSP and enrich Europe's strategic debate. Research areas: EU foreign policy; security and defence policy; disarmament; global governance.

Address: 100 avenue de Suffren, 75015 Paris, France.

Website: http://www.iss.europa.eu

Director: Álvaro de Vasconcelos.

\section{Fraser Institute}

Founded 1974. Independent non-partisan research and educational organization that aims to measure, study and communicate the impact of competitive markets and government interventions on the welfare of individuals. Research covers taxation, government spending, health care, school performance and trade.

Address: 4th Floor, 1770 Burrard St., Vancouver, BC, Canada

V6J 3G7.

Website: http://www.fraserinstitute.org

Director: Brett J. Skinner.

\section{French Institute of International Relations (IFRI)}

Founded 1979. The Institut Français des Relations Internationales is an independent research and debate institution dedicated to international affairs. Research centres on geographic regions as well as economy; energy; Franco-German relations; health/ environment; migration; identities and citizenship; security and defence; space; and sport.

Address: 27 rue de la Procession, 75740 Paris, Cedex 15, France. Website: http://www.ifri.org

Secretary-General: Valérie Genin.

\section{Friedrich Ebert Foundation (Friedrich-Ebert-Stiftung; FES)}

Founded in 1925 as a political legacy of Germany's first democratically elected president, Friedrich Ebert. Non-profit foundation committed to the advancement of public policy issues in the spirit of the basic values of social democracy. Focuses on democracy promotion and international dialogue on the central topics of international politics, globalization, and economic, social and political development in the world.

Address: Berliner Haus, Hiroshimastrasse 17, 10785 Berlin, Germany; Bonner Haus, Godesberger Allee 149, 53175 Bonn, Germany.

Website: http://www.fes.de

President: Peter Struck.

\section{Friedrich Naumann Foundation for Freedom (Friedrich-Naumann-Stiftung für die Freiheit)}

Founded 1958. Non-profit foundation for liberal politics that promotes the goal of making the principle of freedom valid for the dignity of all people and in all areas of society, both in Germany and abroad. Focal issues: freedom and property; freedom and civic society/civil society; freedom and the rule of law.

Address: Karl-Marx-Strasse 2, 14482 Potsdam-Babelsberg,

Germany.

Website: http://www.freiheit.org

Board of Directors President: Dr Wolfgang Gerhardt.

\section{Fundação Getulio Vargas}

Founded 1944. Higher education establishment dedicated to social sciences research to develop the socio-economic position of Brazil. Research covers business, citizenship, education, finance, justice, health, history, law, macro and microeconomics, politics, pollution, poverty and unemployment, sustainable development and welfare.

Address: Praia de Botafogo 190, Rio de Janeiro, 22250-900

Brazil.

Website: http://www.fgv.br

President: Carlos Ivan Simonsen Leal.

\section{German Institute for International and Security Affairs (Stiftung Wissenschaft und Politik; SWP)}

Founded 1962. Independent scientific establishment that conducts practically oriented research on the basis of which it then advises the Bundestag and the German federal government on foreign and security policy issues. Research divisions: EU integration; EU external relations; international security; the Americas; Russian Federation/CIS; Middle East and Africa; Asia; global issues.

Address: Ludwigkirchplatz 3-4, 10719 Berlin, Germany.

Website: http://www.swp-berlin.org

Director: Prof. Dr Volker Perthes.

\section{Heritage Foundation}

Founded 1973. Conservative think tank aiming to formulate and promote public policies based on the principles of free enterprise, limited government, individual freedom, traditional American values and a strong national defence. Target audience includes members of Congress, key congressional staff members, policymakers in the executive branch, the news media, and the academic and public policy communities.

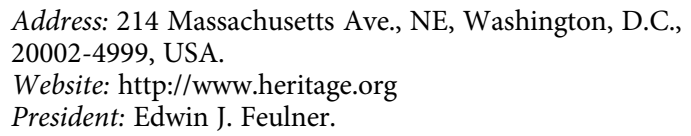

\section{Hoover Institution (on War, Revolution and Peace)}

Founded in 1959 at Stanford University. Originated from research network built up by the Hoover War Library. Aims to secure 